\title{
Work Related Stress of Employees working in Domino's Pizza with Reference to Chennai City Only
}

\author{
Magdalene Peter, S.Fabiyola Kavitha
}

\begin{abstract}
Stress is related with imperatives and requests. The previous keeps a person from doing what the person in question wants. The last alludes to the loss of something wanted. With respect to fulfillment, it might be expressed that individuals who experience pressure secure positions disappointing. Low-to-direct pressure has positive effect on execution. It prompts better execution. While high pressure prompts lower execution. The impact of weight on fulfillment is negative consistently. [1],[3],[5]
\end{abstract}

Keywords : Mental stress, college students, scientific, college students, Dental, students, Engineering, Epidemiology, India

\section{INTRODUCTION}

Stress is commonly comprehended to have antagonistic impact on person's life and association's viability. In spite of the fact that pressure is seen commonly in the negative sense, it has positive side moreover. Eustress is the term used to depict positive pressure. As opposed to this moderate pressure is welcome as it can expand exertion, animate inventiveness and energize determination in one's work. In any case, exorbitantly high pressure can over-burden and breakdown an individual's physical and mental frameworks. Execution can endure as individuals experience disease expedited by exceptional pressure or potentially respond to high worry through non-attendance, turnover, mistakes, disappointment and decreased execution. [13], [15], [17]

\section{OBJECTIVES}

a) Primary:

To study the work related stress of employees working in DOMINO'S PIZZA.

b) Secondary:

i) To study the most stressful aspects of the job.

ii) To study the rate of level of job stress of the employees.

Revised Manuscript Received on July 22, 2019.

Magdalene Peter, Department of MBA, Bharath Institute of Higher Education and Research, Tamilnadu, India. Email: magdalene.bsb@gmail.com Dr.S.Fabiyola Kavitha, Department of MBA, Bharath Institute of Higher Education and Research, Tamilnadu, India. Email: fabiyolakavitha@gmail.com

\section{A. Scope of the study}

This project is intended to study the work related stress of employees in DOMINO'S PIZZA with reference to Chennai city only. [2 ],[4],[6]

\section{B. Limitations:}

1. Collecting information from the employees was difficult.

2. The confidential information cannot be collected due to certain rules and regulations.

3. Time given for doing the project was not enough. [31],[33],[32]

\section{Research Methodology:}

\section{Research Type:}

The exploration strategy embraced for the investigation is Descriptive research. The clear research is likewise called as Explanatory plan. Unmistakable research thinks about for the most part worried about portrayal of attributes of a specific individual or gathering. This exploration incorporates overviews and truth discovering enquiries of various types. The real motivation behind graphic research is portrayal of the situation, as it exists at present. [7], [9] ,[11]

Tools for collecting data:

a) Primary data:

By structured questionnaire method, the primary data was collected from the sample size of 100 employees. [8],[ 10], [12]

b) Secondary data:

The secondary data was gathered from books and websites.

(3) Analysis of data:

The data collected were analysed with the help of tables, percentages and presented by charts.

(4) Sampling Frame:

The sampling frame for the study is focused on the employees working in DOMINOS PIZZA with reference to Chennai only.

(5) Sampling size:

The sample size for the study is 100 employees.

(6) Reference period:

The period used for the project is of three

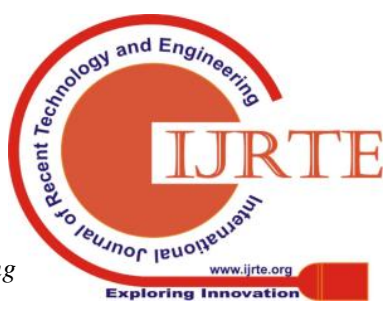


months from January 2011 to March 2011.

Table-1 When the employees are under stress what they

\section{do to overcome stress}

\begin{tabular}{|l|l|l|}
\hline Category & Frequency & Percentage (\%) \\
\hline Meditation & 25 & 25 \\
\hline Games & 32 & 32 \\
\hline Listen to music & 43 & 43 \\
\hline Total & 100 & 100 \\
\hline
\end{tabular}

Interpretation

This table shoes that $25 \%$ of the employees do meditation, $32 \%$ play games and $43 \%$ listen to music to overcome stress.

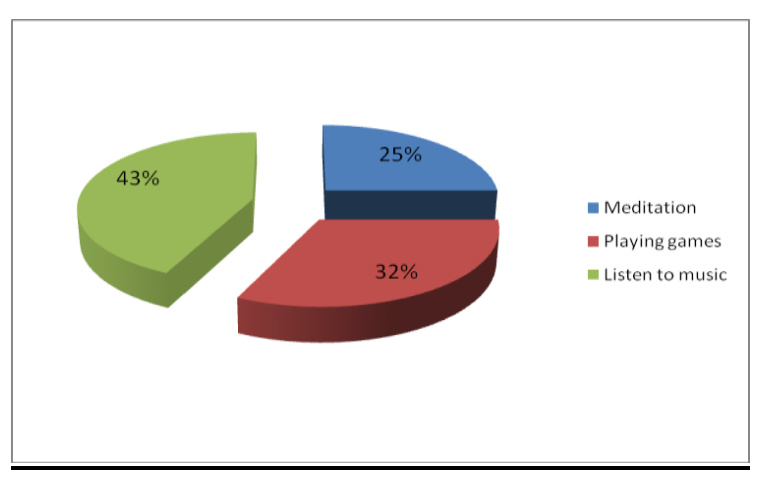

Fig:1 When the employees are under stress what they do to overcome stress.

Inference:

$32 \%$ of the employees listen to music when they are under stress.

Table-2 Whether the company gives training for the employees to avoid the stress

\begin{tabular}{|l|l|l|}
\hline Category & Frequency & Percentage (\%) \\
\hline Yes & 65 & 65 \\
\hline No & 35 & 35 \\
\hline Total & 100 & \\
\hline
\end{tabular}

Interpretation:

This table shows $65 \%$ of the employees had given training by the company to avoid stress and $35 \%$ had not given training.

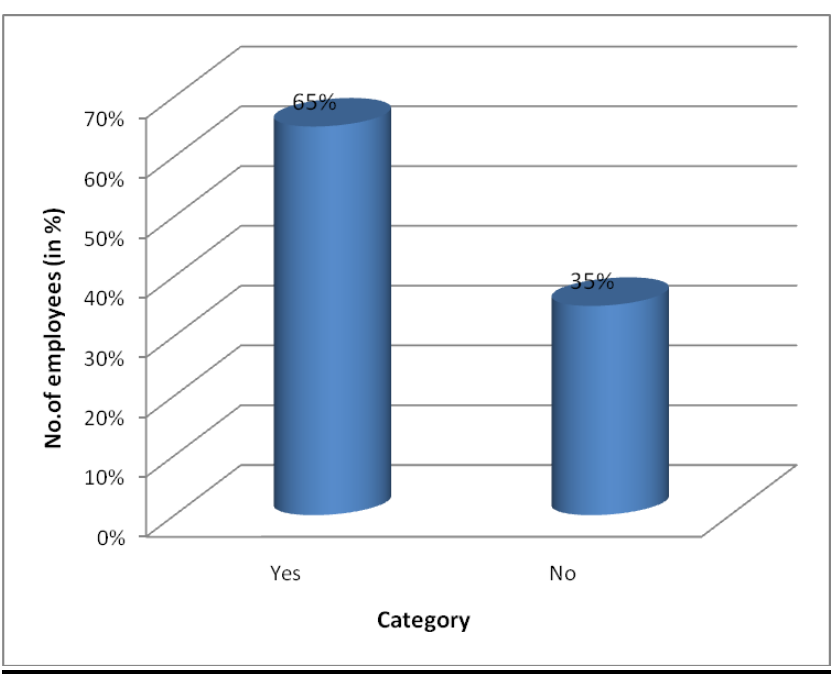

Fig:2 Whether the company gives training for the employees to avoid the stress

\section{Inference:}

$65 \%$ of the employees had given training by the company to avoid stress.

Table-3 Whether the training helps the employees to overcome stress

\begin{tabular}{|l|l|l|}
\hline Category & Frequency & Percentage (\%) \\
\hline Always & 37 & 37 \\
\hline Sometimes & 38 & 38 \\
\hline Never & 25 & 25 \\
\hline Total & 100 & 100 \\
\hline
\end{tabular}

Interpretation:

This table shows that $37 \%$ of the employees says that the training helps them to overcome stress.

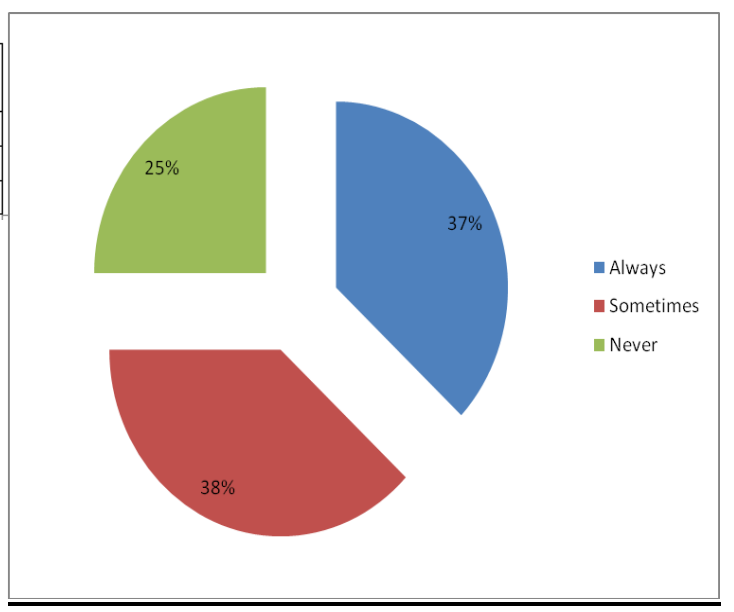

Fig:3 Whether the training helps the employees to overcome stress

Inference:

$38 \%$ of the employees says the training helps them to overcome stress. [26],[28],[30] 
Table-4 Employees suggestions the company can take effective measures to reduce the work stress.

\begin{tabular}{|l|l|l|}
\hline Category & Frequency & \\
\hline By proper stress training & 20 & 20 \\
\hline Proper counselling & 15 & 15 \\
\hline Entertainment & 45 & 45 \\
\hline Tours & 15 & 15 \\
\hline Games & 5 & 5 \\
\hline Total & 100 & 100 \\
\hline
\end{tabular}

\section{Interpretation:}

This table shows that $20 \%$ of the employees says by proper training, $15 \%$ by proper counselling, $45 \%$ by entertainment, $15 \%$ by tours and $5 \%$ by games the company can take effective measures to reduce the work stress

\section{RESULTS}

* About $65 \%$ of the employees are male.

\$ $70 \%$ of the employees are in between the age group of $18-25$.

* About $80 \%$ of the employees work as full time.

* $45 \%$ of the employees work for 45-55 hours in a week.

* $35 \%$ of the employees say work load is the most stressful aspect of their job.

* $37 \%$ of the employees have stress for the whole month. [14],[ 16], [18]

\# $35 \%$ of the employees rate the level of their stress as severe.

* $25 \%$ of the employees feels headache when they are stressful.

* About $22 \%$ of the employees describe their work as challenging one.

\# About $40 \%$ of the employees redouble their efforts when they are given more work.

\# 50\% of the employees accept to work overtime sometimes.

* About $55 \%$ of the employees always get tense when they are given late orders.

\# $76 \%$ of the employees respond in a negative manner when they are asked to do something for which they lack training.

\# $60 \%$ of the employees say their job stress is caused by the co-workers.

\# 53\% of employees say their working environment causes stress for them.

* About $48 \%$ of the employees overcome stress slowly if they a stressful working day.

* $62 \%$ of the employees say the pay given to them causes stress.

\# 50\% of the employees get irritated by the employees little.

* About $32 \%$ of the employees says when they are under stress they listen to music to overcome it.

* About $65 \%$ of the employees had given training to avoid the stress.
$38 \%$ of the employees say the training sometimes helps them to overcome stress.

* About $45 \%$ of the employees say by entertainment the company can take effective measures to reduce the work stress.

\section{DISCUSSION}

* To avoid stress the company should arrange tours and they also can have some games.

* The company should give incentives for the employees who work overtime.

* Festival time holidays should be given to the employees.

* As there is no medical insurance in Dominos, the company should introduce the same.

* Training and development will help employees to develop their skills and equip them to take up other challenges.

* Weekly team review meetings can enhance the team performance as well as individual performance.

* Team outings can bring about more understanding among employees and help to reduce the stress levels.

* The pattern for privileged leaves and flexible timing can help employees to do things of their interests.

* Employing multitasking people can help in reducing the work overloads.

* Work overload can be reduced by effective manpower planning.

* Employees who perform well should be given rewards and awards in order to motivate the employees and to reduce their stress level. [25],[27],[29]

\section{V.CONCLUSION}

A descriptive study is intended to be made on stress management which is very common and complex in nature, particularly in food industries like Dominos where stress is a part of the employees. [19],[21],[23]

All the employees working in Dominos Pizza is having stress.

Majority of the employees says work load is the most stressful aspects of their job.

The company should take effective measures to avoid stress of employees in their job.

Some of the effective measures the company can take are by proper stress training, proper counseling, entertainment, tours, games,etc. [20],[22], [24]

\section{REFERENCES}

1. G BharthVajan R., Ramachandran S.,Psychographic dimensions of training,2016,International Journal of Pharmacy and Technology,V-8,I-4,P-23727-23729

2. Balakrishnan P., Bharthvajan R.,A study on human resource planning in hospitals in Chennai City,2014,International Journal of Applied Engineering Research,V-9,I-22,P-7503-7507

3. Priyadarsini P., Bharthvajan R.,Role of emotional intelligence training programme in reducing the stress of the nurses,2014,International Journal of Applied Engineering Research,V-9,I-22,P-7411-7421

4. Kerinab Beenu G., Bharthvajan R.,Empirical analysis on the cosmetic buying behavior of young women in South India,2014,International Journal of Applied Engineering Research,V-9,I-22,P-7361-7366

5. Balakrishnan P., Bharthvajan R.,Whistling in the wind,2014,International Journal of Applied Engineering Research,V-9,I-22,P-7586-7593

6. Krishnan B., Peter M.,Health hazards of Indian Bpo

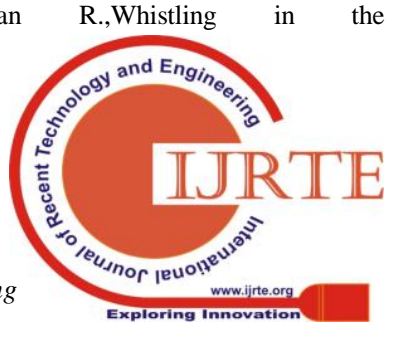


employee-an alarming issue,2014,International Journal of Applied Engineering Research,V-9,I-22,P-7336-7341

7. Kerinab Beenu G.H., Peter M.,Role of insurance in economic development,2014,International Journal of Applied Engineering Research,V-9,I-22,P-7532-7539

8. Balakrishnan P., Peter M., Priyadarsini P.,Efficiency of safety measures for wellbeing of employees in manufacturing industry,2014,International Journal of Applied Engineering Research,V-9,I-22,P-7376-7382

9. Anbarasi M., Praveen Kumar S.,Online sales promotions of herbal products and its effectiveness towards tanisha.com,2019,Indian Journal of Public Health Research and Development,V-10,I-1,P-195-200

10. Anbarasi M., Praveen Kumar S.,Various online marketing and promotions strategies to improve the validation towards the organic products in the pharmaceutical sectors,2019, Indian Journal of Public Health Research and Development,V-10,I-1,P-263-269

11. Loganathan R., Praveen Kumar S.,Grievance handling a key factor for solving issues of employees in an organization,2014,International Journal of Applied Engineering Research,V-9,I-22,P-7483-7491

12. Loganathan R., Praveen Kumar S.,Study on preference of private label brands in super and Hypermarkets, 2014,International Journal of Applied Engineering Research,V-9,I-22,P-7327-7335

13. Smitha M., Praveen Kumar S.,Understanding stress and its managementamong the nurses in Chennai city,2014,International Journal of Applied Engineering Research,V-9,I-22,P-7560-7565

14. Kerinab Beenu G.H., Praveen Kumar S.,A study on the investment behavior of Chennai investors in mutual fund schemes,2014,International Journal of Applied Engineering Research,V-9,I-22,P-7520-7525

15. Loganathan R., Praveen Kumar S.,Retention strategies key for organizational productivity,2014,International Journal of Applied Engineering Research,V-9,I-22,P-7443-7447

16. Pavithra J., Ganesan M., Brindha G.,State wise analysis of microfinance sector in India,2016,International Journal of Pharmacy and Technology,V-8,I-4,P-23417-23432

17. Pavithra J., Ganesan M.,A comparative study on microfinance in India and abroad,2016,International Journal of Applied Business and Economic Research,V-14,I-8,P-5471-5476

18. Pavithra J., Ganesan M.,A study on awareness and impact of micro-financial schemes,2016,International Journal of Applied Business and Economic Research,V-14,I-8,P-5449-5460

19. Senthilmurugan P., Pavithra J.,Consumer preference towards organised retailing with reference to Big Bazaar,2014,International Journal of Applied Engineering Research,V-9,I-22,P-7469-7475

20. Senthilmurugan P., Pavithra J.,Implication of social media marketing in growing healthcare industry,2014,International Journal of Applied Engineering Research,V-9,I-22,P-7448-7456

21. Loganathan R., Pavithra J.,Consumer perception towards private label brand over other brands in super markets and hypermarkets,2014,International Journal of Applied Engineering Research,V-9,I-22,P-7355-7360

22. Kerinab Beenu G., Pavithra J.,Tradeâ€"off between liquidity and profitability in logistics industry,2014,International Journal of Applied Engineering Research,V-9,I-22,P-7398-7401

23. Kerinab Beenu G., Pavithra J.,A study on the prospective consumerâ€TM perception towards utility cars in Chennai city,2014,International Journal of Applied Engineering Research,V-9,I-22,P-7526-7531

24. Pavithra J., Dilli Babu P., Ambuli T.V.,A study on budgetary control at Maruti Service Masters, Chennai,2014,International Journal of Applied Business and Economic Research,V-12,I-2,P-151-161

25. Pavithra J., Dilli Babu P., Ambuli T.V.,A study on customer satisfaction of retro Garments Pvt Ltd, Chennai,2014,International Journal of Applied Business and Economic Research,V-12,I-2,P-381-391

26. Kerinab Beenu G.H., Pavithra J., Senthilmurugan P.,A study on the influence of promotional activities for TATA ARIA among consumers in Chennai,2014,International Journal of Applied Engineering Research,V-9,I-22,P-7572-7578

27. Vijayaragavan S.P.,An investigative expert that's general FBG sensors, International Journal of Mechanical Engineering and Technology,V-8,I-8,PP-1500-1505,Y-2017

28. Vijayaragavan S.P.,Equalization routing protocol for $\mathrm{Wi}-\mathrm{Fi}$ sensor strategy,International Journal of Mechanical Engineering and Technology,V-8,I-8,PP-1662-1666,Y-2017

29. Karthik B., Kiran Kumar T.V.U., Vijayaragavan P., Bharath Kumaran E.,Design of a digital PLL using 0.35 $\hat{\mathrm{I}}^{1 / 4 \mathrm{~m}}$ CMOS technology,Middle East Journal of Scientific Research,V-18,I-12,PP-1803-1806,Y-2013

30. Kanniga E., Selvaramarathnam K., Sundararajan M.,Kandigital bike operating system,Middle - East Journal of Scientific Research,V

31. Jasmin M., Vigneshwaran T., Beulah Hemalatha S.,Design of power aware on chip embedded memory based FSM encoding in FPGA,International Journal of Applied Engineering Research,V-10,I-2,PP-4487-4496,Y-2015
32. Jasmin M.,Optimization techniques for low power VLSI circuits,Middle East Journal of Scientific Research,V-20,I-9,PP-1082-1087,Y-2014

33. Jasmin M., Vigneswaran T.,Fuzzy controller for error control of on - Chip communication,2017 International Conference on Algorithms, Methodology, Models and Applications in Emerging Technologies, ICAMMAET 2017,V-2017-January,I-,PP-1-5,Y-2017

\section{AUTHORS PROFILE}

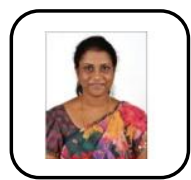

Magdalene Peter,Assistant Professor ,Department of MBA, Bharath Institute of Higher Education and Research, Tamilnadu, India

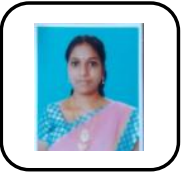

Dr.S.Fabiyola Kavitha, Associate Professor Departmen of MBA, Bharath Institute of Higher Education and Research, Tamilnadu, India 